\title{
Morphological and molecular characterisation of Aporocotyle margolisi Smith, 1967 (Digenea: Aporocotylidae) from the North Pacific hake Merluccius productus (Ayres) (Gadiformes: Merlucciidae) off Oregon, USA
}

\author{
Jesus S. Hernández-Orts • David I. Hernández-Mena • Gema Alama-Bermejo • \\ Roman Kuchta $\cdot$ Kym C. Jacobson
}

Received: 2 March 2017 / Accepted: 2 June 2017

(C) Springer Science+Business Media B.V. 2017

\begin{abstract}
Aporocotylid blood flukes conspecific with Aporocotyle margolisi Smith, 1967 were collected from the bulbus arteriosus of the North Pacific hake Merluccius productus (Ayres). This study revisits the morphology of A. margolisi, including drawings, measurements and scanning electron microscopy images, and provides for the first time molecular data for the large subunit of the ribosomal RNA (28S rDNA) and the mitochondrial cytochrome $c$ oxidase subunit $1(\operatorname{cox} 1)$ genes for this species. A $28 \mathrm{~S}$ rDNA
\end{abstract}

This article is part of the Topical Collection Digenea.

Electronic supplementary material The online version of this article (doi:10.1007/s11230-017-9740-6) contains supplementary material, which is available to authorized users.

Jesus S. Hernández-Orts and David I. Hernández-Mena have contributed equally to this work.

J. S. Hernández-Orts $(\bowtie) \cdot$ G. Alama-Bermejo

Centro de Investigación Aplicada y Transferencia

Tecnológica en Recursos Marinos Almirante Storni

(CIMAS - CCT CONICET - CENPAT) y Escuela

Superior de Ciencias Marinas (ESCiMar), Universidad

Nacional del Comahue, Güemes 1030,

8520 San Antonio Oeste, Río Negro, Argentina

e-mail: jesus.hernandez.orts@gmail.com

\section{I. Hernández-Mena}

Laboratorio de Helmintología, Instituto de Biología, Universidad Nacional Autónoma de México, Avenida Universidad 3000, Ciudad Universitaria,

04510 Mexico City, Mexico phylogenetic study of $A$. margolisi, and all available Aporocotyle spp., was also performed. The distribution range of $A$. margolisi is extended to the Pacific coast of the USA. We provide a morphological comparison of Aporocotyle spp. from the Pacific coast in North America as well as other Aporocotyle spp. infecting hake. Comparisons with the original description revealed that the new specimens of A. margolisi were considerably larger with respect to all morphological features, except for shorter spines. Molecular results showed a close relationship between A. margolisi and A. argentinensis Smith, 1969 from the Argentine hake Merluccius hubbsi Marini. The phylogenetic relationships of Aporocotyle spp. point to a possible co-speciation of hakes species and these blood fluke parasites.

\author{
D. I. Hernández-Mena \\ Posgrado en Ciencias Biológicas, Universidad Nacional \\ Autónoma de México, Ciudad Universitaria, \\ 04510 Mexico City, Mexico \\ G. Alama-Bermejo · R. Kuchta \\ Institute of Parasitology, Biology Centre of the Czech \\ Academy of Sciences, 37005 Ceské Budějovice, \\ Czech Republic \\ G. Alama-Bermejo \\ Department of Microbiology, Oregon State University, \\ Corvallis, OR 97331, USA
}




\section{Introduction}

Aporocotyle Odhner, 1900, the type-genus of the family Aporocotylidae Odhner, 1900 (see Bullard et al., 2009), is a prominent group of digeneans among marine fishes (Gadiformes, Ophidiiformes, Perciformes, Pleuronectiformes and Scorpaeniformes) (see Hernández-Orts et al., 2012, and references therein). These cosmopolitan trematodes, also known as fish blood flukes, as adults commonly parasitise the gill blood-vessels, heart and bulbus arteriosus of fish.

Five species of Aporocotyle have been described from hake Merluccius spp. (Gadiformes: Merlucciidae) from the Atlantic and Pacific Oceans. These include A. argentinensis Smith, 1969 from the Argentine hake M. hubbsi Marini; A. australis Fernández \& Durán, 1985 from the southern hake $M$. australis (Hutton); A. margolisi Smith, 1967 from the North Pacific hake M. productus (Ayres); A. spinosicanalis Williams, 1958 from the European hake $M$. merluccius (L.); and A. wilhelmi Villalba \& Fernández, 1986 from the South Pacific hake M. gayi gayi (Guichenot) (see Williams, 1958; Smith, 1967, 1969; Fernández \& Durán, 1985; Villalba \& Fernández, 1986a). These five species are morphologically very similar, and have been identified exclusively by morphological traits (e.g. body length, number of testes, oesophagus to body length ratio and anterior caeca to posterior caeca ratio) and by the definitive host species (Hernández-Orts et al., 2012, and references therein). In contrast, the application of molecular methods for species identification of these blood flukes remains poorly explored. Molecular data for only a few molecular markers (i.e. small and large subunits of the ribosomal RNA gene) are available in the GenBank database, and only for A. argentinensis and A. spinosicanalis (see Snyder \& Loker, 2000; Olson et al., 2003; Hernández-Orts et al., 2012).

During a survey of parasites of the North Pacific hake M. productus off the Oregon coast, USA, in 2016, aporocotylid trematodes were found in the bulbus arteriosus. Detailed morphological analysis suggested that these worms are conspecific with A. margolisi described by Smith (1967) from M. productus off

\section{K. C. Jacobson}

Newport Research Station, Northwest Fisheries Science Center, National Marine Fisheries Service, 2030 S.E.

Marine Science Dr., Newport, OR 97365, USA
Vancouver Island, British Columbia, Canada. This paper provides a complete morphological description of the newly-collected worms, including for the first time, scanning electron micrographs of this blood fluke. Additionally, partial sequences for the large subunit of the ribosomal RNA gene (28S rDNA) and cytochrome $c$ oxidase subunit 1 mitochondrial gene ( $\operatorname{cox} 1)$ for this species are provided for the first time.

\section{Materials and methods}

\section{Sample collection}

A total of $14 \mathrm{M}$. productus (total length $40.0-46.1 \mathrm{~cm})$, was collected in July 2016 off Newport $\left(44^{\circ} 28^{\prime} 55^{\prime \prime} \mathrm{N}, 124^{\circ} 31^{\prime} 08^{\prime \prime} \mathrm{W}\right)$, Oregon, USA. Fish were collected by commercial bottom trawling vessels and kept fresh on ice. The heart, bulbus arteriosus and ventral aorta were removed, placed in Petri dishes with saline solution and examined under a stereomicroscope. Blood flukes were gently washed in saline and immediately fixed and stored in $4 \%$ formaldehyde solution $(\mathrm{n}=2), 2.5 \%$ glutaraldehyde in PBS $(\mathrm{pH}$ 7.2) $(\mathrm{n}=2)$ or in $100 \%$ ethanol $(\mathrm{n}=3)$.

\section{Morphological data}

Two specimens fixed in $4 \%$ formaldehyde solution were used for the morphological study. These worms were stained with iron acetocarmine, dehydrated in an ethanol series, cleared in dimethyl phthalate and examined as permanent mounts in Canada balsam. Specimens were examined using an Olympus BX51 microscope (Olympus Corporation, Tokyo, Japan) with differential interference contrast optics. Drawings were made using a drawing attachment on the microscope. Measurements were taken using the Olympus Quick-Photo Image-Program, and are given in micrometres unless otherwise stated. Voucher specimens are deposited in the Smithsonian National Museum of the Natural History, Washington, D.C., USA (USNM) and the Helminthological Collection of the Institute of Parasitology, Czech Academy of Sciences, České Budějovice, Czech Republic (IPCAS).

Two specimens fixed in $2.5 \%$ glutaraldehyde were prepared for scanning electron microscopy (SEM). These specimens were washed in $0.1 \mathrm{M}$ sodium cacodylate buffer ( $\mathrm{pH}$ 7.2), dehydrated in an ethanol series and transferred to hexamethyldisilazane (HMDS) (Ted Pella, Inc., Redding, USA), and allowed 
to air-dry. They were subsequently mounted on aluminium stubs using double-sided carbon tape, sputter coated with 30-nm gold/palladium, and examined with a Jeol JSEM 7401F microscope (JEOL Ltd., Tokyo, Japan) at the Laboratory of Electron Microscopy, Biology Centre, Czech Academy of Sciences, at an accelerating voltage of $4 \mathrm{kV}$.

\section{Molecular data}

Two specimens fixed in $100 \%$ ethanol were individually digested overnight at $56^{\circ} \mathrm{C}$ in a solution containing $10 \mathrm{mM}$ Tris- $\mathrm{HCl}$ (pH 7.6), $20 \mathrm{mM} \mathrm{NaCl}$, $100 \mathrm{mM}$ Na2 EDTA (pH 8.0), 1\% Sarkosyl, and $0.1 \mathrm{mg} / \mathrm{ml}$ proteinase $\mathrm{K}$. DNA was isolated from the supernatant using the DNAzol (Molecular Research Center, Cincinnati, USA) following the manufacturer's instructions. The domains D1, D2 and D3 of the $28 \mathrm{~S}$ rDNA (c.1,100 nt) were amplified using the forward primer $502\left(5^{\prime}\right.$-CAA GTA CCG TGA GGG AAA GTT GC- $\left.3^{\prime}\right)$ and the reverse primer $536\left(5^{\prime}-\right.$ CAG CTA TCC TGA GGG AAA C-3') (GarcíaVarela \& Nadler, 2005). The cytochrome $c$ oxidase subunit 1 (cox 1$)$ gene $(c .600 \mathrm{nt})$ was amplified with the forward primer Plat-diploCOXF (5'-CGT TTR AAT TAT ACG GAT CC- $3^{\prime}$ ) and the reverse primer PlatdiploCOXR (5'-AGC ATA GTA ATM GCA GCA GC-3') (Moszczynska et al., 2009). Polymerase chain reaction (PCR) amplifications were carried out with $2 \mu \mathrm{l}$ of DNA extraction supernatant, $1 \mu \mathrm{l}$ of each PCR primer $(10 \mu \mathrm{M}), 0.5 \mu \mathrm{l}$ of dNTPs $(10 \mathrm{mM})$ and $1 \mathrm{U}$ of Vivantis Taq DNA Polymerase with $2.5 \mu \mathrm{l}$ of $10 \times$ ViBuffer A, and $1.5 \mathrm{mM}$ of $\mathrm{MgCl}_{2}$ (Vivantis Technologies Sdn. Bhd., Selangor Darul Ehsan, Malaysia). The following amplification profile was used for both molecular markers: $95{ }^{\circ} \mathrm{C}$ for 5 min (denaturation); 35 cycles of $94{ }^{\circ} \mathrm{C}$ for $1 \mathrm{~min}, 50{ }^{\circ} \mathrm{C}$ for $1 \mathrm{~min}$ and $72{ }^{\circ} \mathrm{C}$ for $1 \mathrm{~min}$; and a final extension of $72{ }^{\circ} \mathrm{C}$ for $10 \mathrm{~min}$. PCR products for $28 \mathrm{~S}$ rDNA were sequenced with the PCR primers plus internal primers 503 (5'-CCT TGG TCC GTG TTT CAA GAC G-3'; Stock et al., 2001) and $504\left(5^{\prime}\right.$-CGT CTT GAA ACA CGG ACT AAG G-3'; García-Varela \& Nadler, 2005). PCR products for $\operatorname{cox} 1$ were sequenced with the PCR primers. PCR products were sequenced using an ABI 3730xl Genetic Analyser (Applied Biosystems, Foster City, USA). The consensus sequences were obtained from the individual sequences amplified from each primer using the program Geneious Pro 4.8.4 ${ }^{\circledR}$ (Biomatters
Ltd., Auckland, New Zealand). Sequences were submitted to GenBank under accession numbers MF287915, MF287916, MF314114 and MF314115.

Phylogenetic analyses were only performed for $28 \mathrm{~S}$ rDNA sequences, as there are no cox 1 sequences for Aporocotyle spp. available on GenBank. The newly generated sequences for the $28 \mathrm{~S}$ rDNA were aligned with the sequences of other four species of Aporocotyle available on GenBank using ClustalW (Thompson et al., 1997), implemented in the web http://www. genome.jp/tools/clustalw/. The sequence for $\mathrm{Pa}$ radeontacylix ibericus Repullés-Albelda, Montero, Holzer, Ogawa, Hutson \& Raga, 2008 was used as the outgroup in the analyses of 28S rDNA (AM489593; Repullés-Albelda et al., 2008). Phylogenetic analyses were run under maximum likelihood (ML) and Bayesian inference (BI), employing the model of nucleotide evolution GTR + GAMMA estimated with jModelTest v2 (Darriba et al., 2012). ML analysis was performed in RAxML v. 7.0.4 (Stamatakis, 2006) with 10 replicates. All model parameters and bootstrap support values (500 repetitions) were estimated with RAxML. BI analysis was carried out using MrBayes v.3.2 (Ronquist et al., 2012). BI log-likelihoods were estimated running two independent Markov Chain Monte Carlo runs of two chains each run for one million generations and sampling tree topologies every 100 generations. 'Burn-in' periods were set to the first 500 generations. A 50\% majority-rule consensus tree and nodal support estimated as posterior probability (PP) values were calculated from the remaining trees. The phylogenetic trees obtained from ML and BI analysis were visualized in FigTree v.1.4.2. Genetic divergence for the $28 \mathrm{~S}$ rDNA dataset was calculated as uncorrected p-distance using MEGA v6 (Tamura et al., 2013).

\section{Family Aporocotylidae Odhner, 1912 Genus Aporocotyle Odhner, 1900}

\section{Aporocotyle margolisi Smith, 1967}

Host: Merluccius productus (Ayres) (Gadiformes: Merlucciidae), North Pacific hake (type-host).
Locality:
Off
Newport
$\left(44^{\circ} 28^{\prime} 55.2^{\prime \prime} \mathrm{N}\right.$,
$\left.124^{\circ} 31^{\prime} 08.3^{\prime \prime} \mathrm{W}\right)$, Oregon, USA. 


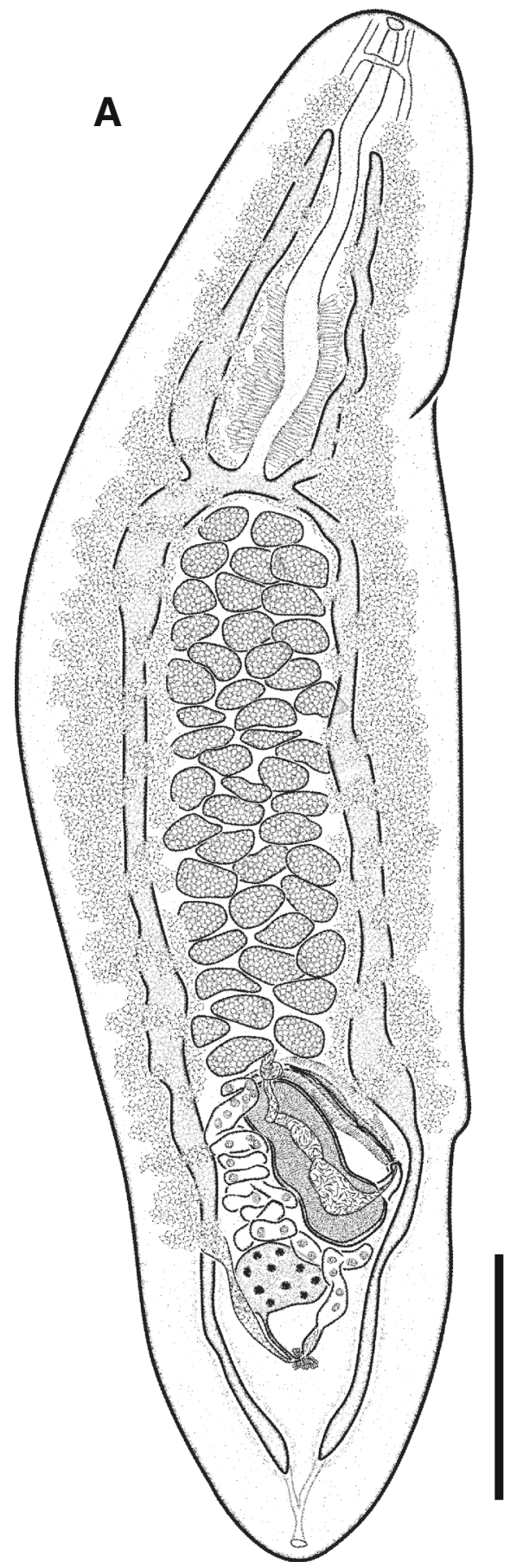

B
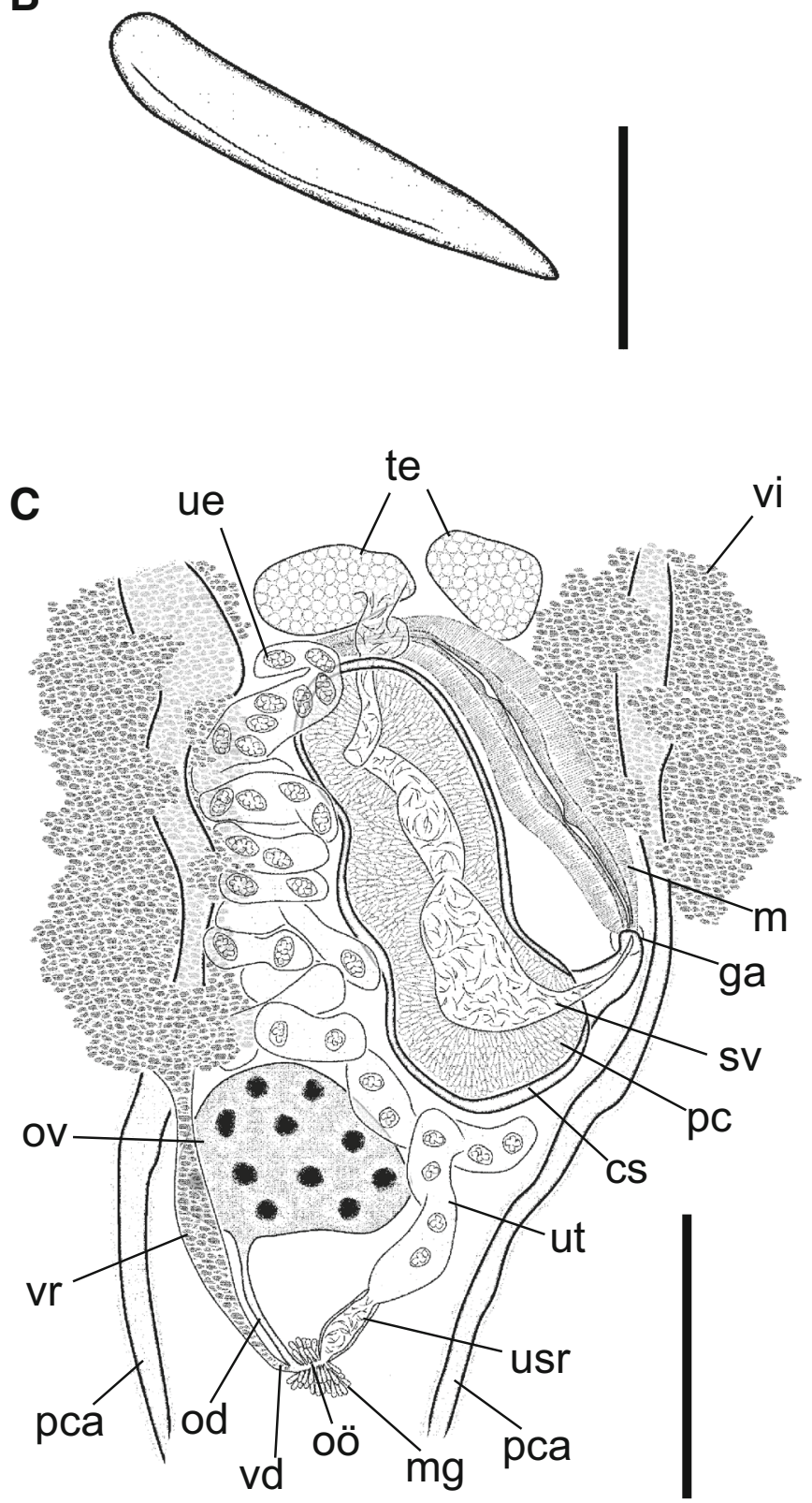

Fig. 1 Aporocotyle margolisi Smith, 1967 ex Merluccius productus (Ayres) off Oregon, USA. Voucher (USNM 1422204). A, Whole worm, ventral view; B, Tegumental spine; C, Reproductive organs. Abbreviations: cs, cirrus-sac; ga, genital atrium; m, metraterm; mg, Mehlis' gland; od, oviduct; oö, oötype; ov, ovary; pc, prostatic cells; pca, posterior caeca; sv, seminal vesicle; te, testes; ue, uterine egg; usr, uterine seminal receptacle; ut, uterus; vd, vitelloduct; vi, vitellarium; vr, vitelline reservoir. Scale-bars: A, 1,000 $\mu \mathrm{m}$; B, $5 \mu \mathrm{m}$; C, $500 \mu \mathrm{m}$ 
Site in host: Bulbus arteriosus.

Infection parameters: Prevalence: 29\% $(\mathrm{n}=14)$; abundance: 0.5 worms per fish; mean intensity: 1.8 worms per infected fish; intensity range 1-2.

Voucher material: USNM 1422204; IPCAS D-751.

Representative DNA sequences: MF287915, MF287916 (28S rDNA); MF314114, MF314115 $(\cos 1)$.

\section{Description (Figs. 1-2)}

[Based on 2 mounted specimens and 2 specimens examined by SEM; measurements in Table 1.] Body elongate, with blunt anterior extremity and slightly pointed posterior extremity (Figs. 1A, 2A, B); maximum width approximately at midbody or at posterior third of body. Tegumental spines short, pointed (Figs. 1B, 2C-E), forming clusters of c.30 to 35 spines each (Fig. 2D, E); ventral cluster of spines distributed along ventro-marginal areas of body, joining at sagittal axis from posterior margin of mouth to approximately caecal bifurcation; dorsal cluster arranged along dorso-lateral body margins, never joining at sagittal axis; clusters of spines less abundant at posterior half body.

Oral sucker absent. Mouth subterminal; buccal capsule not observed. Oesophagus long, surrounded by glands from its posterior third quarter to caeca bifurcation. Intestine H-shaped. Anterior caeca similar in length, extending anteriorly to approximately first quarter of oesophagus. Posterior caeca somewhat similar in length, extending to almost posterior extremity of body (Fig. 1A).

Testes subspherical to transversely-oval, intercaecal, between caecal bifurcation and reproductive organs (Fig. 1A). Vas deferens extending from posterior margin of testicular field. Cirrus-sac claviform, with thick muscular wall, slightly constricted in one or two places, directing sinistrally, ending in genital atrium, contains elongate and slightly sinuous seminal vesicle surrounded by numerous prostatic cells (Fig. 1C). Cirrus not observed. Genital atrium and genital pore sinistral, intercaecal, at about 24.2-25.6\% of body length from posterior extremity of body.

Ovary slightly dextral, intercaecal, transverselyoval to subtriangular (Fig. $1 \mathrm{~A}, \mathrm{C}$ ), at about $14.5-16.0 \%$ of body length from posterior body extremity. Oviduct long, runs sinistrally from posterior margin of ovary (Fig. 1C). Mehlis' gland small, well developed, surrounding oötype. Uterine seminal receptacle elongated, thick-walled (Fig. 1C). Laurers' canal not observed. Uterus intercaecal, forming several transverse coils from uterine seminal receptacle to posterior margin of testicular field. Metraterm muscular, parallel to cirrus-sac (Fig. 1C). Vitellarium follicular, compact. Vitelline fields mostly dorsal to caeca, from level well posterior of nerve commissure to anterior margin of ovary on dextral side, and anterior to genital atrium on sinistral side. Vitelline reservoir elongated, anterior to ovary. Vitelloduct connects to oviduct near oötype. Fully developed eggs thin-shelled, ellipsoidal.

Nerve commissure ventral, approximately at first fifth of oesophagus (Fig. 1A). Nerve cords extending anteriorly to posterior margin of mouth, indistinct posteriorly. Excretory vesicle Y-shaped; excretory pore subterminal.

\section{Remarks}

All specimens found in M. productus from off Oregon exhibit all the morphological characteristics of Aporocotyle; they possess tegumental spines arranged in clusters (although single spines, not clusters, were recently described in A. michaudi Santoro, Cipriani, Pankov \& Lawton, 2015 by Santoro et al., 2015), $\mathrm{H}$-shaped intestine, more than 18 intercaecal testes, ovary located near posterior extremity, largely preovarian uterus, and pre-ovarian common genital atrium (Smith, 2002). To our knowledge, only $A$. margolisi and A. macfarlani Holmes, 1971, have been described from fishes from the North Pacific coast of North America (Smith 1967; Holmes, 1971; Hernández-Orts et al., 2012).

Our specimens are morphologically very similar to A. margolisi, described from the bulbus arteriosus of the same host species. A comparison between specimens previously collected from British Columbia and our specimens from off Oregon revealed higher upper limits for almost all metrical data in the newlycollected specimens (Table 1). Therefore, our study extends the known range for body size, the length of the oesophagus, anterior and posterior caeca, the size of the cirrus-sac, ovary, Mehlis' gland and eggs, and the length of the uterine seminal receptacle and metraterm. Only the tegumental spines were somewhat shorter in the present specimens compared with the original description. Our study provides detailed 

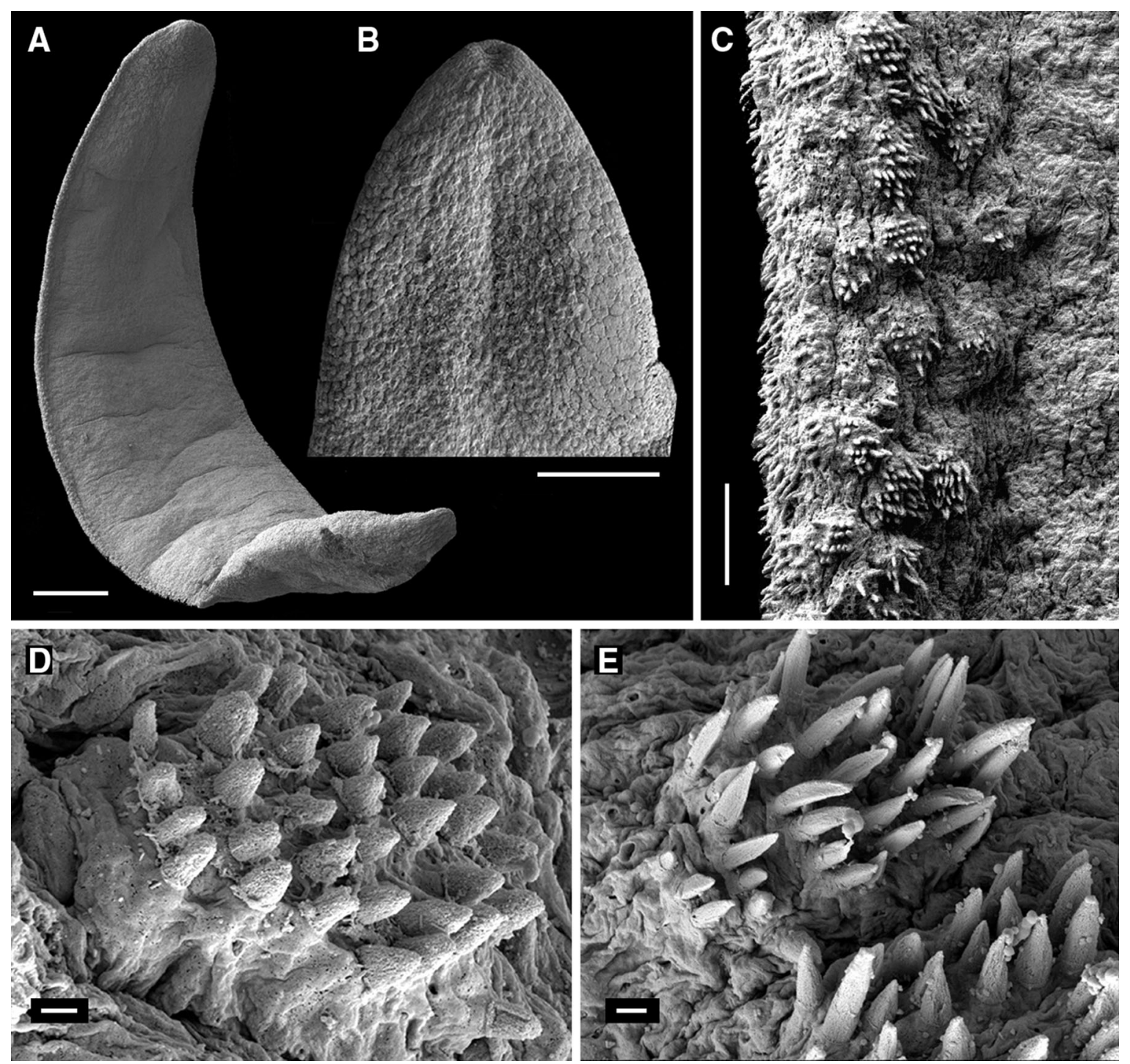

Fig. 2 Scanning electron micrographs of Aporocotyle margolisi Smith, 1967 ex Merluccius productus (Ayres) off Oregon, USA. A, Whole worm; B, Anterior part of the worm, ventral view; C, Ventro-lateral body area showing the distribution of spine cluster; D, E, Details of clusters of spines. Scale-bars: A, $300 \mu \mathrm{m}$; B, $200 \mu \mathrm{m} ; \mathrm{C}, 20 \mu \mathrm{m}$; D, E, $1 \mu \mathrm{m}$

data on the morphometric variability of this species, and extends the knowledge of its distributional range further south to the Pacific coast of the USA.

The newly-collected material differed from $A$. macfarlani, described in sebastid fishes (Scorpaeniformes: Sebastidae) from off the San Juan Islands, Washington (USA), and off Bamfield, and Departure Bay, British Columbia (Canada), in having a longer body, considerably longer oesophagus, anterior and posterior caeca, cirrus-sac, metraterm and eggs (Table 1), and by having a thick muscular cirrus-sac, which is slightly constricted in one or two places ( $v s$ a cirrus-sac without constrictions). Additionally, $A$. margolisi and A. macfarlani parasitise fish hosts of different families (Merlucciidae $v s$ Sebastidae).

Molecular results from the present study showed a close relationship between A. margolisi described herein from off Oregon and A. argentinensis from off Argentina (see below). Both species use hake as definitive hosts and are morphologically similar (see Supplementary Table S1). However, A. argentinensis differs from A. margolisi in having a narrower body, 
Table 1 Comparative measurements of Aporocotyle spp. from the Northeast Pacific off North America

\begin{tabular}{|c|c|c|c|}
\hline \multirow{3}{*}{$\begin{array}{l}\text { Species } \\
\text { Host } \\
\text { Locality }\end{array}$} & \multicolumn{2}{|l|}{ A. margolisi Smith, 1967} & \multirow{5}{*}{$\begin{array}{l}\text { A. macfarlani Holmes, } 1971 \\
\text { Sebastes spp. } \\
\text { Off Washington, USA; British } \\
\text { Columbia, Canada } \\
\text { Holmes (1971) } \\
\text { Range }(\mathrm{n}=103)\end{array}$} \\
\hline & Merluccius productus (Ayres) & M. productus & \\
\hline & Off Vancouver Island, British & Off Newport, & \\
\hline Source & Smith (1967) & Present study & \\
\hline & Range $(\mathrm{n}=3)$ & Range $(\mathrm{n}=2)$ & \\
\hline Body length (mm) & $3.82-4.96$ & $6.37-7.74$ & $3.26-5.18$ \\
\hline Maximum body width (mm) & $1.14-1.39$ & $1.59-1.81$ & $0.47-1.06$ \\
\hline Spine length & 17 & $11-13$ & 14 \\
\hline Number of spines per cluster & $20-40$ & $30-35$ & $20-50$ \\
\hline Oesophagus length & $1,070-1,430$ & $1,908-2,175$ & $1,342^{\mathrm{a}}$ \\
\hline Oesophagus to body length ratio & $1: 3.47-3.83$ & $1: 3.34-3.56$ & $1: 3.39^{\mathrm{a}}$ \\
\hline $\begin{array}{l}\text { Maximum extension of posterior } \\
\text { caeca }\end{array}$ & Posterior body end & Posterior body end & Posterior body end \\
\hline Anterior caeca length & $1,224-1,240^{\mathrm{a}}$ & $1,492-1,719$ & $380-876$ \\
\hline $\begin{array}{l}\text { Anterior caeca to posterior caeca } \\
\text { length ratio }\end{array}$ & $1: 2.78-3.01^{\mathrm{a}}$ & $1: 2.74-3.52$ & $1: 5.40-5.50$ \\
\hline Posterior caeca length & $3,444-3,685^{\mathrm{a}}$ & $4,175-5,405$ & $1,400-3,540$ \\
\hline Posterior caeca to body length ratio & $1: 1.35-1.44^{\mathrm{a}}$ & $1: 1.43-1.52$ & $1: 1.45-1.49^{\mathrm{a}}$ \\
\hline Number of testes & $35-46$ & $42-47$ & $37-63$ \\
\hline Maximum testis diameter & $133-215^{\mathrm{a}}$ & $157-298$ & $121-210^{\mathrm{a}}$ \\
\hline Cirrus-sac length & $510-680$ & $955-1,025$ & $130-260$ \\
\hline Cirrus-sac width & $200-310$ & $335-369$ & $70-150$ \\
\hline $\begin{array}{l}\text { Distance from posterior extremity to } \\
\text { genital pore }\end{array}$ & $1,000-1,390$ & $1,630-1,875$ & $1,236^{\mathrm{a}}$ \\
\hline Ovary length & $280-290$ & $312-329$ & $142-340$ \\
\hline Ovary width & $150-200$ & $400-421$ & $90-220$ \\
\hline Mehlis' gland length & $97^{\mathrm{a}}$ & $72-125$ & $132^{\mathrm{a}}$ \\
\hline Mehlis' gland width & $111^{\mathrm{a}}$ & $57-110$ & $101^{\mathrm{a}}$ \\
\hline Uterine seminal receptacle length & $82^{\mathrm{a}}$ & $155-208$ & - \\
\hline Metraterm length & $400^{\mathrm{a}}$ & $745-818$ & $146-287$ \\
\hline Egg length & 43 & $54-59$ & $36-48$ \\
\hline Egg width & 22 & $32-37$ & $26-37$ \\
\hline $\begin{array}{l}\text { Distance from anterior extremity to } \\
\text { nerve commissure }\end{array}$ & 160 & $195-310$ & 230 \\
\hline
\end{tabular}

${ }^{a}$ Estimated from the published drawing

shorter anterior and posterior caeca, cirrus-sac, ovary, metraterm and smaller eggs. Moreover, A. argentinensis and A. margolisi are found in hakes from the Southern and Northern hemisphere, respectively.

An additional three species of Aporocotyle have been described from three species of hake, i.e. $A$. australis ex $M$. australis, A. spinosicanalis ex $M$. merluccius and A. wilhelmi ex M. gayi gayi (see Supplementary Table S1). Aporocotyle australis possesses a somewhat longer oesophagus in relation to body length, a greater number of testes, a smaller cirrus-sac and a shorter ovary than A. margolisi. Aporocotyle spinosicanalis differs from A. margolisi in having a shorter oesophagus in relation to body length and smaller anterior caeca to posterior caeca length ratio, and in having fewer testes and smaller eggs (see Supplementary Table S1). Finally, $A$. wilhelmi can be differentiated from A. margolisi by 
Table 2 Species of aporocotylid digeneans included in the phylogenetic analyses with data for hosts and localities and GenBank accession numbers

\begin{tabular}{|c|c|c|c|c|}
\hline Species & Host & Locality & GenBank ID & Source \\
\hline \multicolumn{5}{|l|}{ Aporocotylidae Odhner, 1912} \\
\hline \multicolumn{5}{|l|}{ Aporocotyle Odhner, 1900} \\
\hline A. argentinensis Smith, 1969 & $\begin{array}{l}\text { Merluccius } \\
\quad \text { hubbsi Marini }\end{array}$ & $\begin{array}{l}\text { Off Patagonia, } \\
\text { Argentina }\end{array}$ & JX094803 & $\begin{array}{l}\text { Hernández-Orts } \\
\text { et al. (2012) }\end{array}$ \\
\hline $\begin{array}{l}\text { A. mariachristinae Hernández-Orts, Alama-Bermejo, } \\
\text { Carrillo, García, Crespo, Raga \& Montero, } 2012\end{array}$ & $\begin{array}{c}\text { Genypterus } \\
\text { blacodes } \\
\text { (Forster) }\end{array}$ & $\begin{array}{l}\text { Off Patagonia, } \\
\text { Argentina }\end{array}$ & JX094802 & $\begin{array}{l}\text { Hernández-Orts } \\
\text { et al. (2012) }\end{array}$ \\
\hline A. michaudi Santoro, Cipriani, Pankov \& Lawton, 2015 & $\begin{array}{r}\text { Trematomus } \\
\text { bernacchii } \\
\text { Boulenger }\end{array}$ & $\begin{array}{l}\text { Ross Sea, } \\
\text { Antarctica }\end{array}$ & KR025807 & $\begin{array}{l}\text { Santoro et al. } \\
\text { (2015) }\end{array}$ \\
\hline A. margolisi Smith, 1967 & $\begin{array}{c}\text { Merluccius } \\
\text { productus } \\
\text { (Ayres) }\end{array}$ & $\begin{array}{l}\text { Off Oregon, } \\
\text { USA }\end{array}$ & $\begin{array}{l}\text { MF287915; } \\
\text { MF287916 }\end{array}$ & Present study \\
\hline \multirow[t]{2}{*}{ A. spinosicanalis Williams, 1958} & \multirow[t]{2}{*}{$\begin{array}{l}\text { Merluccius } \\
\quad \text { merluccius (L.) }\end{array}$} & North Sea & AF167094 & $\begin{array}{l}\text { Snyder \& } \\
\quad \text { Loker (2000) }\end{array}$ \\
\hline & & $\begin{array}{l}\text { Off Orkney } \\
\text { Islands, } \\
\text { Scotland }\end{array}$ & AY222177 & $\begin{array}{l}\text { Olson et al. } \\
\quad(2003)\end{array}$ \\
\hline \multicolumn{5}{|l|}{ Outgroup } \\
\hline \multicolumn{5}{|l|}{ Paradeontacylix McIntosh, 1934} \\
\hline $\begin{array}{l}\text { P. ibericus Repullés-Albelda, Montero, Holzer, Ogawa, } \\
\text { Hutson \& Raga, } 2008\end{array}$ & $\begin{array}{l}\text { Seriola dumerili } \\
\quad \text { (Risso) }\end{array}$ & $\begin{array}{l}\text { Off Murcia, } \\
\text { Spain }\end{array}$ & AM489593 & $\begin{array}{l}\text { Repullés- } \\
\text { Albelda et al. } \\
\text { (2008) }\end{array}$ \\
\hline
\end{tabular}

its shorter anterior and posterior caeca, and by its smaller cirrus-sac and ovary. Furthermore, A. wilhelmi possess a buccal capsule $(90 \times 30 \mu \mathrm{m}$; see figure 6 in Villalba \& Fernández, 1986a), a morphological feature not observed in other species of Aporocotyle from hakes.

\section{Molecular analyses}

Four partial sequences were generated for A. margolisi; two for 28S rDNA (1,168-1,242 nt) and two for cox1 (640-667 nt). The aligned 28S rDNA dataset included seven sequences (six for Aporocotyle spp. and one for $P$. ibericus used as the outgroup, see Table 2 for details), and comprised 1,187 nt positions after trimming the ends to match the shortest aligned sequence. Both, maximum likelihood and Bayesian inference analyses of the 28S rDNA dataset resulted in consensus trees with generally similar topologies (Fig. 3). ML and BI analyses revealed a close relationship between the sequences for $A$. margolisi and a clade formed by A. argentinensis (Fig. 3), both species parasitizing hakes from the Northeast Pacific and the southwestern Atlantic Oceans, respectively. Molecular data obtained in the present study clearly supported the differentiation between A. spinosicanalis and A. margolisi (Fig. 3). Genetic divergence within Aporocotyle ranged from $0.5 \%$ (5 nt) (A. margolisis vs A. argentinensis) to $6.7 \%$ (66 nt) (A. spinosicanalis vs A. michaudi). Finally, sequences for cox 1 from two isolates of A. margolisi from Oregon were identical, and represent the first published molecular data for this molecular marker for a species of Aporocotyle.

\section{Discussion}

The present study revealed a high morphological variability in most metrical features of A. margolisi from $M$. productus. Our results suggest that the size of A. margolisi does not depend on the size of the fish, as 


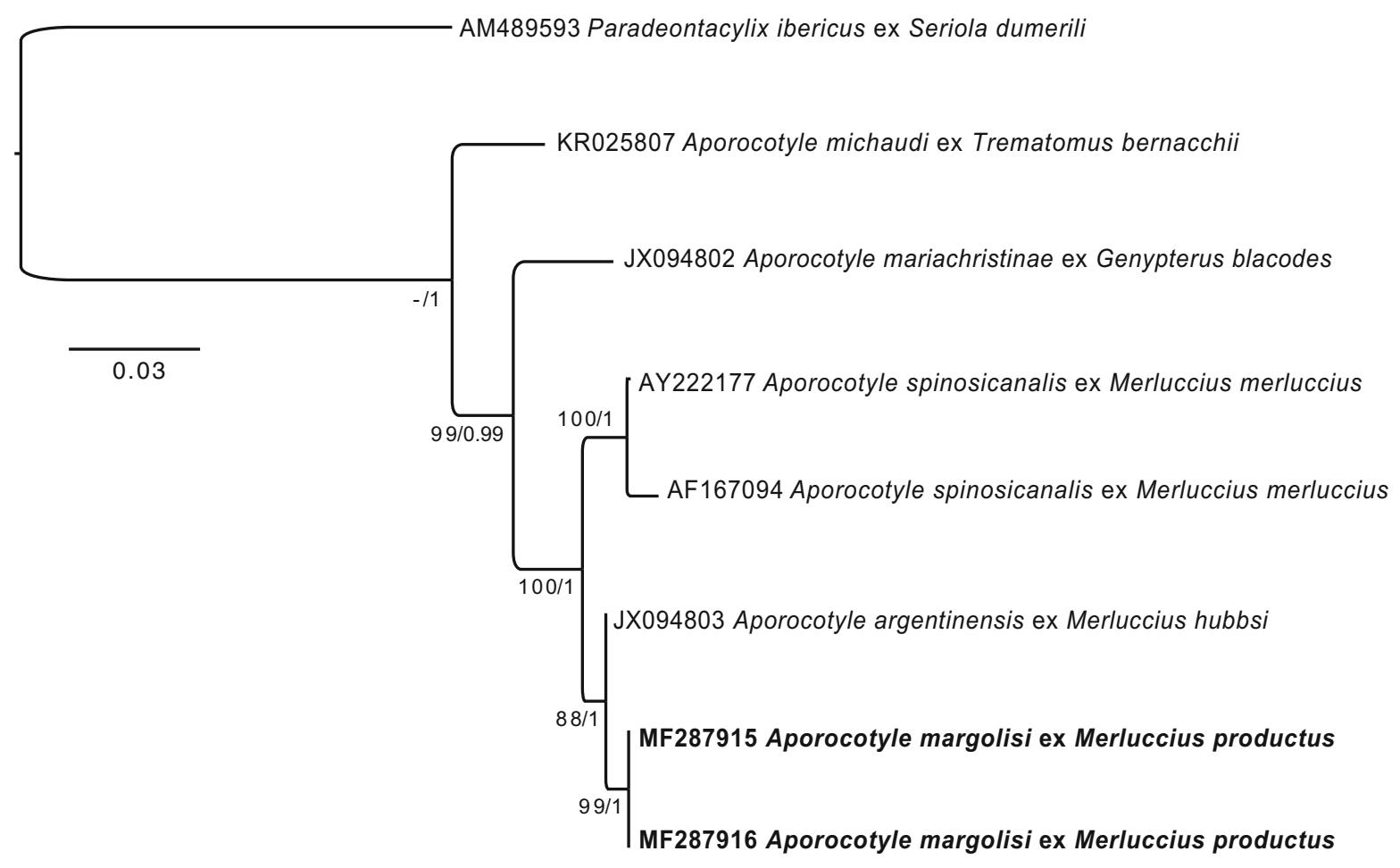

Fig. 3 Maximum likelihood inference phylogram employing a GTR + GAMMA substitution model for the 28S rDNA dataset. Numbers represent nodal supports from ML analysis (bootstrap values $>70 \%$ shown only) followed by posterior probabilities from BI analysis ( $>0.95$ shown only). The scale-bar indicates the expected number of substitutions per site. The newly generated sequences are indicated in bold

the small specimens of A. margolisi described by Smith (1967), were collected from larger hakes than the specimens from the present study $(47-69 \mathrm{~cm} v \mathrm{~s}$ 40.0-46.1 cm, respectively) (see Table 2). Specimens of A. margolisi from both studies were fixed postmortem in 4\% formaldehyde solution (Smith, 1967; see above), and therefore it seems unlikely that the morphological differences could be influenced by the method of fixation. However, Smith (1967) fixed and preserved the heart and bulbus arteriosus in 4\% formaldehyde before removing the worms, whereas in our study, blood flukes were removed from fresh bulbus arteriosus before fixation.

Currently, 18 species are placed in Aporocotyle (see table 1 in Hernández-Orts et al., 2012; Santoro et al., 2015). In fact, due to the large number of species described in Aporocotyle, this genus represents the second most diverse group of marine fish blood flukes, just after the widely distributed genus Cardicola Short, 1953 (see Orélis-Ribeiro et al., 2014).
Morphological data from species of Aporocotyle are abundant (e.g. see table 1 in Hernández-Orts et al., 2012). Indeed, morphological data have been used to assess some phylogenetic relationships of Aporocotyle spp. from hakes or cusk-eels Genypterus spp. (Ophidiiformes: Ophidiidae) (e.g. Smith, 1969; Fernández \& Duran, 1985; Villalba \& Fernández, 1986b). The systematics and phylogeny of species of Aporocotyle based on molecular data is relatively depauperate. Partial sequences for ribosomal gene molecular markers are available for only five species (OrélisRibeiro et al., 2014; Santoro et al., 2015; present study). Recently Cifuentes Riquelme (2015) suggested, based on a molecular study, that the diversity of aporocotylids from hake and cusk-eels from the Pacific and Atlantic coasts of South America may be overestimated. Unfortunately, the sequences obtained by Cifuentes Riquelme (2015) are currently not available in the GenBank database, and could not be used in our phylogenetic analysis. The application of 
molecular methods in future taxonomic studies of fish blood flukes of the genus Aporocotyle is clearly necessary for species identification and delineation.

Molecular phylogenetic studies of hake (Merluccius spp.) revealed a close relationship between the species occurring in the West Atlantic (e.g. M. hubbsi) and East Pacific (e.g. M. productus), which clearly separates from the Euro-African species (e.g. $M$. merluccius) (see Quinteiro et al., 2000; Campo et al., 2007, 2009). Our phylogenetic analyses obtained with the molecular data for Aporocotyle spp. suggested a pattern of association of the blood flukes with their hake host species. The phylogenetic tree suggests two distinct clades for the Aporocotyle spp. from hakes (Fig. 3): (i) one clade contains A. spinosicanalis ex $M$. merluccius from the North East Atlantic; and (ii) a second clade with A. margolisi ex M. productus from the Northeast Pacific as a sister taxon to A. argentinensis ex M. hubbsi from the Southwest Atlantic. Our phylogenetic results may indicate a possible cospeciation of these blood flukes with their hake hosts. However further research is needed to confirm the intimate relationship, i.e. co-evolution, co-speciation and co-adaptation between a blood fluke and its hake host species.

Acknowledgements We are grateful to Heather Munro Mann (Midwater Trawlers Cooperative, Newport, Oregon) for providing the fish analysed in this study. We also thank Alejandro Oceguera for his assistance with the molecular analyses. Institutional support was given to D.I.H.-M. by the Posgrado en Ciencias Biológicas, Universidad Nacional Autónoma de México.

Funding This study was supported by the Czech Science Foundation (projects ECIP P505/12/G112 and GP14-28784P), the Institute of Parasitology, Biology Centre of the Czech Academy of Sciences (grant number RVO: 60077344) and the Programa de Apoyo a Proyectos de Investigación e Innovación Tecnológica (PAPIIT)-UNAM (project IA202016). D.I.H.-M. benefits from a $\mathrm{PhD}$ student grant from the Posgrado en Ciencias Biológicas, Universidad Nacional Autónoma de México, and from the National Council on Science and Technology (CONACyT) of the Mexican Government (scholarship number 245193).

\section{Compliance with ethical standards}

Conflict of interest The authors declare that they have no conflict of interest.

Ethical approval All applicable institutional, national and international guidelines for the care and use of animals were followed.

\section{References}

Bullard, S. A., Jensen, K., \& Overstreet, R. M. (2009). Historical account of the two family-group names in use for the single accepted family comprising the "fish blood flukes". Acta Parasitologica, 54, 78-84.

Campo, D., Machado-Schiaffino, G., Horreo, J. L., \& GarciaVazquez, E. (2009). Molecular organization and evolution of 5S rDNA in the genus Merluccius and their phylogenetic implications. Journal of Molecular Evolution, 68, 208-216.

Campo, D., Machado-Schiaffino, G., Perez, J., \& Garcia-Vazquez, E. (2007). Phylogeny of the genus Merluccius based on mitochondrial and nuclear genes. Gene, 30, 171-179.

Cifuentes Riquelme, M. (2015). Filogenia de Aporocotyle spp. (Digenea) en sus hospedadores del género Merluccius y Genypterus, en Chile. Bachelor's Thesis, Valdivia, Universidad Austral de Chile, 40 pp.

Darriba, D., Taboada, G. L., Doallo, R., \& Posada, D. (2012). jModelTest 2: More models, new heuristics and parallel computing. Nature Methods, 9, 772.

Fernández, J., \& Durán, L. (1985). Aporocotyle australis n. sp. (Digenea: Sanguinicolidae), parásito de Merluccius australis (Hutton 1872) en Chile y su relación con la filogenia de Aporocotyle Odhner, 1900 en Merluccius spp. Revista Chilena de Historia Natural, 58, 121-126.

García-Varela, M., \& Nadler, S. A. (2005). Phylogenetic relationships of Palaeacanthocephala (Acanthocephala) inferred from SSU and LSU rDNA gene sequences. Journal of Parasitology, 91, 1401-1409.

Hernández-Orts, J. S., Alama-Bermejo, G., Carrillo, J. M., García, N. A., Crespo, E. A., Raga, J. A., et al. (2012). Aporocotyle mariachristinae n. sp., and A. ymakara Villalba \& Fernández, 1986 (Digenea: Aporocotylidae) of the pink cusk-eel, Genypterus blacodes (Ophidiiformes: Ophidiidae) from Patagonia, Argentina. Parasite, 19, 319-330.

Holmes, J. C. (1971). Two new sanguinicolid blood flukes (Digenea) from scorpaenid rockfishes (Perciformes) of the Pacific coast of North America. Journal of Parasitology, 57, 209-216.

Moszczynska, A., Locke, S. A., McLaughlin, J. D., Marcogliese, D. J., \& Crease, T. J. (2009). Development of primers for the mitochondrial cytochrome c oxidase I gene in digenetic trematodes (Platyhelminthes) illustrates the challenge of barcoding parasitic helminths. Molecular Ecology Resources, 9, 75-82.

Olson, P. D., Cribb, T. H., Tkach, V. V., Bray, R. A., \& Littlewood, D. T. J. (2003). Phylogeny and classification of the Digenea (Platyhelminthes: Trematoda). International Journal for Parasitology, 33, 733-755.

Orélis-Ribeiro, R., Arias, C. R., Halanych, K. M., Cribb, T. H., \& Bullard, S. A. (2014). Diversity and ancestry of flatworms infecting blood of nontetrapod craniates "fishes". Advances in Parasitology, 85, 1-64.

Quinteiro, J., Vidal, R., \& Rey-Méndez, M. (2000). Phylogeny and biogeographic history of hake (genus Merluccius), inferred from mitochondrial DNA control-region sequences. Marine Biology, 136, 163-174. 
Repullés-Albelda, A., Montero, F. E., Holzer, A. S., Ogawa, K., Hutson, K. S., \& Raga, J. A. (2008). Speciation of the Paradeontacylix spp. (Sanguinicolidae) of Seriola dumer$i l i$. Two new species of the genus Paradeontacylix from the Mediterranean. Parasitology International, 57, 405-414.

Ronquist, F., Teslenko, M., van der Mark, P., Ayres, D. L., Darling, A., Höhna, S., et al. (2012). MrBayes 3.2: Efficient Bayesian phylogenetic inference and model choice across a large model space. Systematic Biology, 61, 539-542.

Santoro, M., Cipriani, P., Pankov, P., \& Lawton, S. P. (2015). Aporocotyle michaudi n. sp. (Digenea: Aporocotylidae) from the emerald rock cod, Trematomus bernacchii (Teleostei: Perciformes) in Antarctica. Parasitology International, 64, 324-329.

Smith, J. W. (1967). Aporocotyle margolisi n. sp. (Digenea: Aporocotylidae) from Merluccius productus. Journal of the Fisheries Research Board of Canada, 24, 1763-1773.

Smith, J. W. (1969). On Aporocotyle argentinensis n. sp. (Digenea: Sanguinicolidae) from Merluccius hubbsi, and the phylogeny of Aporocotyle Odhner, 1900 in hake. Journal of Helminthology, 43, 371-382.

Smith, J. W. (2002). Family Sanguinicolidae von Graff, 1907. In: Gibson, D. I., Jones, A. \& Bray, R. A. (Eds), Keys to the Trematoda, Volume 1. Wallingford: CABI Publishing and the Natural History Museum, pp. 433-452.

Snyder, S. D., \& Loker, E. S. (2000). Evolutionary relationships among the Schistosomatidae (Platyhelminthes: Digenea) and an Asian origin for Schistosoma. Journal of Parasitology, 86, 283-288.
Stamatakis, A. (2006). RAxML-VI-HPC: Maximum likelihoodbased phylogenetic analyses with thousands of taxa and mixed models. Bioinformatics, 22, 2688-2690.

Stock, S. P., Campbell, J. F., \& Nadler, S. A. (2001). Phylogeny of Steinernema travassos, 1927 (Cephalobina: Steinernematidae) inferred from ribosomal DNA sequences and morphological characters. Journal of Parasitology, 87, 877-889.

Tamura, K., Stecher, G., Peterson, D., Filipski, A., \& Kumar, S. (2013). MEGA6: molecular evolutionary genetics analysis version 6.0. Molecular Biology and Evolution, 30, 2725-2729.

Thompson, J. D., Gibson, T. J., Plewniak, F., Jeanmougin, F., \& Higgins, D. G. (1997). The CLUSTAL_X windows interface: flexible strategies for multiple sequence alignment aided by quality analysis tools. Nucleic Acids Research, 15, 4876-4882.

Villalba, C., \& Fernández, J. (1986a). Dos nuevas especies de trematodos parásitos de peces marinos en Chile. Parasitología al Día, 10, 45-51.

Villalba, C., \& Fernández, J. (1986b). Tres nuevas especies de Aporocotyle Odhner, 1900 (Digenea: Sanguinicolidae) parasitas de Genypterus spp. en Chile (Pisces: Ophidiidae). Revista de Biología Marina, Valparaíso, 22, 125-139.

Williams, H. H. (1958). The anatomy of Aporocotyle spinosicanalis sp. nov. (Trematoda: Digenea) from Merluccius merluccius (L.). Annals and Magazine of Natural History Series, 13, 291-297. 